\title{
Analysis about the Awareness of the Oral Consequences of Consuming Tobacco Products among College Students
}

\author{
Preethitha Sabesan
}

\begin{abstract}
Aim: The aim of this study is to conduct a survey among the college students about the awareness of the harm full effects of tobacco products on the oral health. Materials and method: A questionnaire containing 16 questions about the various effects of tobacco products on oral health was distributed among 120 students from different colleges. The answered questionnaires were collected and subjected to descriptive analysis to analyse the level of awareness among these students. Result: At the end of the study it is found that about $55.16 \%$ of the students who answered the questionnaire showed moderate to high level of awareness and about $44.83 \%$ of students did not have adequate awareness about the harmful consequences of tobacco consumption on the oral cavity.
\end{abstract}

Keywords: awareness, tobacco consumption, oral consequences, college students.

\section{Introduction}

Oral Health is an important aspect to estimate the general health of a person. The awareness about the maintenance of oral health has been increased throughout the years. Yet proper knowledge on the pathogenesis, signs and symptoms etc are not understood by the majority of the population. Caners are the most common cause of death world wide, increasing the death rate tremendously. Although a definite cause of a number of cancers are not known, the cause of oral cancer, which the second common cancer in India is found to be primarily due to consumption of tobacco products.

Tobacco is consumed in a variety of different ways, though smoking of manufactured cigarettes is the most prevalent form of its use.Bidi smoking is a popular form of tobacco use in south Asia, accounting for one-third of the tobacco produced in India for smoking (1). There has been a rapid increase in trade and use of smokeless tobacco products in recent years in the country, which is a matter of serious concern to the health planners (2).

Cigarette smoking is a major public health problem in bothdeveloping and developed countries. Globally, there are 1.3billion smokers of which $80 \%$ live in developing countries andby the year 2030 the deaths toll will increase from 5.4million deaths per year to more than 8 million deaths a year (3).

College life is an important transition period during whichyoung adults begins to explore tobacco use (4). Many studieshave reported that tobacco smoking is rising in youngadult between the ages of 18-24 years as they are legaltargets of tobacco industry marketing and increased theprevalence of smoking among college students (5)(6). Thestudy conducted in Asian countries like Pakistan, Chinaand India also showed there was high prevalence oftobacco smoking among college students (7)(8)(9).

India is the second most populous country in the world.India is the third largest producer and consumer of tobacco in the world. The country has a long history of tobacco use. Tobacco is used in a variety of ways in India; its use has unfortunately been well recognised among the adolescents (10-21).

\section{Materials and Method}

Questionnaires containing 16 items were distributed among students from various colleges. The questionnaires did not contain any question about the personal information like name or place of the participants. The questionnaire contained basic questions about the tobacco habits, if present their willingness to give up the habit and then proceeded towards questions about their knowledge about the effects of tobacco on teeth, periodontal tissues, oral mucosa, its effects on general health, basic signs of carcinoma, incidence of oral carcinoma in tobacco consumers, prevalence of oral carcinoma in India, death rate in India due to oral carcinoma. The questionnaire is close ended and the students were asked to choose yes if they were aware of that fact and no if they were not aware of it previously. The students were allowed to ask their doubts to the representative present while answering the questionnaire. From around 120 questionnaires distributed, 100 students returned the answered questionnaire which is $83 \%$ of the total sample size. The answered questionnaires were analysed statistically to find out the average awareness of the students who participated.

\section{Results}

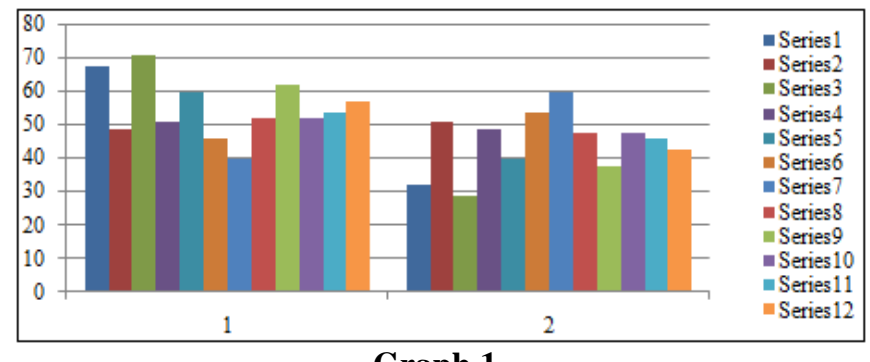

Graph 1

Graph 1 show the number of yes or no choice made for each question. Each series denotes the respective question. The set 1 denotes the yes choices made and set 2 denotes the number of no choice made for that question.

\section{Volume 6 Issue 7, July 2017 www.ijsr.net}


International Journal of Science and Research (IJSR)

ISSN (Online): 2319-7064

Index Copernicus Value (2015): 78.96 | Impact Factor (2015): 6.391

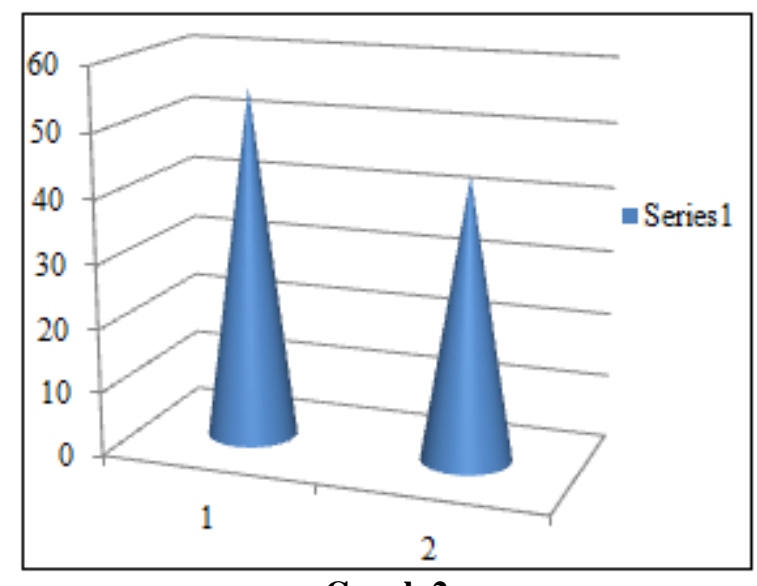

Graph 2

The graph 2 denotes the total number of yes and no choices made to the questions in the questionnaire. The set 1 denotes the total number of yes and set 2 denotes the total number of no choice made.

Each of the yes choice made signifies that the participant was aware of the information asked in that question and the no choice denotes that the participant was not aware of the given fact. There were a total of 55.16 yes choices and 44.18 no choice made on an average. This value denotes the corresponding level of awareness among the participants.

The survey shows that $44 \%$ of the participants who answered the questionnaire were tobacco product users. Out of that $34 \%$ of participants tried giving up the habit, however only $22 \%$ of the participants were not successful in giving up the habit. $80 \%$ of participants were confident that they were aware of the harmful consequences while $20 \%$ were not aware.

$78 \%$ of the participants were aware that a tobacco product increases the incidents of dental caries and $49 \%$ were aware that tobacco products affect the periodontal health. $71 \%$ of participants were aware that tobacco increases the chances of getting cancer and $51 \%$ knew that there are about 60 carcinogenic chemicals in tobacco products. Only $46 \%$ of participants were aware that tobacco had addictive effect similar to nicotine and $40 \%$ were aware that India stand second in the death rate due to tobacco products. $62 \%$ of the participants were aware that $32 \%$ of people diagnosed with oral carcinoma die within 5 years. $52 \%$ of the participants were aware that consuming tobacco products can reduce the life span upto $18-20 y e a r s$ and $57 \%$ of participants were aware that not using tobacco products can increase the life span by 5-8 years.

\section{Discussion}

The level of awareness among the students is $55.16 \%$ according to this survey. Although this is much higher than the results from the past, for a country like India which is the third largest producer of tobacco products and second largest country in the incidents of oral carcinoma, this level of awareness is not adequate to effectively reduce the incidence of carcinoma. The Government of India has recently taken some important legal measures, but there are still many problems in the enforcement of tobacco related law.
Restrictions have been imposed on sales and on tobacco use in public places like railway stations, airports, hospitals and governmental offices. However, the more important aspect would be the strict observation and control of such restrictions. The sales of all tobacco products including the MSTP and their easy access strongly need to be banned for children and adolescents. An initiative in this regard has been taken by stopping tobacco sale in vicinity of schools (22).

\section{Conclusion}

The level of awareness is not sufficient to effectively improve the health status in India. Therefore more awareness programs and effective counselling must be made focussing the younger generation as the main target population. This is because of the high incidence of tobacco consumption among the younger generation seen recently. This can be done by conducting camps, promotional posters, ads, and educating the tutors on the consequences, methods of prevention etc. so that they can help the students.

\section{References}

[1] http://www.eaom.eu/files/tobacco.pdf

[2] Tobacco use by Indian adolescents RK Chadda, corresponding author and SN Sengupta, TobInduc Dis. 2003; 1(1): 8 Published online 2002 Jun 15. doi: 10.1186/1617-9625-1-8.

[3] World Health Organization. The WHO Reports on theGlobal Tobacco Epidemic. Geneva, 2008

[4] Thompson B, Coronado G, Chen L, Thompson LA, Halperin A, Jaffe R, et al. Prevalence and characteristics of smokers at 30 Pacific Northwest colleges and universities. Nicotine Tob Res 2007; 9:429-38.

[5] Rigotti NA, Lee JE, Wechsler H. US college students' use of tobacco products: results of a national survey. JAMA 2000;284:699-705. PMid: 12034976.

[6] Rigotti NA, Regan S, Majchrzak NE, et al. Tobacco use byMassachusetts public college students: long term effect of the Massachusetts Tobacco Control Program. Tob Control2002;11 Suppl 2:ii20-4. PMid: 17976241.

[7] Rozi S, Butt ZA, Akhtar S. Correlates of cigarette smoking among male college students in Karachi, Pakistan. BMCPublic Health 2007;7:312)

[8] Nichter M, Van Sickle D. Popular perceptions of tobacco products and patterns of use among male college students in India. SocSci Med 2004;59:415-31.

[9] Mao R, Li X, Stanton B, Wang J, Hong Y, Zhang H,et al.Psychosocial correlates of cigarette smoking among college students in China. Health Educ Res 2009; 24:105-18.

[10] Patel DR. Smoking and children. Indian Journal of Pediatrics. 1999; 66:817-24. doi: 10.1007/BF02723844. [PubMed]

[11] Sinha DN, Gupta PC. Tobacco and areca nut use in male medical students of Patna. National Medical Journal of India. 2001; 14:176-178. [PubMed]

[12] Kapoor SK, Anand K, Kumar G. Prevalence of tobacco use among school and college going adolescents of Haryana. Indian Journal of Pediatrics. 1995; 62:461466. doi: 10.1007/BF02755068. [PubMed]

\section{Volume 6 Issue 7, July 2017 www.ijsr.net}




\section{International Journal of Science and Research (IJSR) \\ ISSN (Online): 2319-7064}

Index Copernicus Value (2015): 78.96 | Impact Factor (2015): 6.391

[13] Krishnamurthy S, Ramaswamy R, Trivedi U, Zachariah V. Tobacco use in rural Indian children. Indian Pediatrics. 1997;34:923-927. [PubMed]

[14] Venkatraman S, Mukhopadhya A, Muliyil J. Trends of smoking in medical students. Indian Journal of Medical Research. 1996;104:316-320. [PubMed]

[15] Vaidya SG, Naik UD, Vaidya JS. Effect of sports sponsorship by tobacco companies on children's experimentation with tobacco. British Medical Journal. 1996;313(7054):375 [PubMed]

[16] George A, Varghese C, Sankaranarayanan R, Nair MK. Use of tobacco and alcoholic beverages by children and teenagers in a low income coastal community in south India. Journal of Cancer Research. 1994;9:111-113. [PubMed]

[17] Jayant K, Notani PN, Gulati SS, Gadre VV. Tobacco use in school children in Bombay, India. A study of knowledge, attitude and practice. Indian Journal of Cancer. 1991;28:139-147. [PubMed]

[18] Gavarasana S, Doddi VP, Prasad GV, Allam A, Murthy BS. A smoking survey of college students in India: Implications for designing an antismoking policy. Japanese Journal of Cancer Research. 1991;82:142-145. [PubMed]

[19] Gavarasana S, Gorty PV, Allam A. Illiteracy, ignorance and willingness to quit smoking among villagers in India. Japanese Journal of Cancer Research. 1992;83:340-343. [PubMed]

[20] Singh SK, Narang RK, Chandra S, Chaturvedi PK, Dubey AL. Smoking habits of the medical students. Indian Journal of Chest Diseases and Allied Sciences. 1989;31:73-75. [PubMed])

[21] Singhi S, Broca JS, Mathur GM. Smoking behaviour of rural schoolboys. Indian Pediatrics. 1987;24:655-659.

[22] Gupta PC. Gutka: a major new tobacco hazard in India. Tobacco Control. 1999;8:132. doi: 10.1136/tc.8.2.132b 